\title{
UTILIZATION OF ELECTRICITY IN AGRICULTURE AND HORTICULTURE
}

$\mathrm{I}^{\mathrm{N}}$ the report referred to below*, which was prepared originally for the guidance of the Electrical Research Association, Mr. C. A. Cameron Brown gives a very complete review of the experimental and research side of rural electrification. It is estimated that out of about a quarter of a million farms in Great Britain which are already, or are likely soon to be, within reasonable reach of an electric supply, only about one in eight has yet been connected. The main difficulty in the way of further development is the relatively high cost of providing a supply to the average farm. Most electrical development is based on the expectation that a new customer will bring in an annual revenue equal to about 20 per cent of the capital cost of connecting him to the system. Under present conditions, however, the average annual revenue from a newly-connected farm is unlikely to exceed $£ 25$; while the cost of connexion will almost certainly be considerably more than five times this amount. There are two possible lines along which a solution of this difficulty might be sought : to lower costs of connexion by simplification, standardization or other means ; or to increase potential revenue by encouraging the wider application of electrical power on the farm ; and it is to consideration of the second of these that the report is mainly directed.

Of the various fields of activity in which farmers use power, tillage is by far the largest and most important; but, from the point of view of electrical development, is one of the least hopeful. Batterydriven tractors are out of the question, while electrically operated winding sets, working on the same principle as steam ploughing engines, are too restricted in operation for the present-day farmer. The only real possibility lies in the electrically driven tractor fed from a stationary supply point, through a flexible cable which is paid out and picked up automatically as the machine manceuvres. The main technical problem is the design of a cable-winding mechanism which will give the tractor sufficient flexibility of movement ; and it seems unlikely that electrically operated outfits will ever be able to undertake much field work beyond ploughing and the heavier cultivations. Their development would therefore seem to be quite out of tune with the present overwhelming tendency towards all-purpose tractors which can also be used for the after-cultivations of growing crops, and in haymaking, harvesting, transport and so on. Some practical progress in electrical tillage has, however, been made in New Zealand.

In the barnyard, where power may be needed for water supply, grinding and a whole range of food preparing operations, as well as for such subsidiary work as wood-sawing, the position is much more hopeful. In nearly all such operations, electrical power has the advantage of greater convenience; and although few directly comparable costs are available, there is good reason to believe that electric motors will give lower overall running costs than

- A Critical Study of the Application of Electricity to Agriculture and Horticulture. By C. A. Cameron Brown. (Technical Report Ref W/T2.) Pp. 84. (London: British Electrical and Allied Industries Research Association, 1940.) 28. stationary internal combustion engines, provided that electrical power is available at rather less than $2 d$. per kilowatt hour. There is, however, room for developmental research : both into the kind of layout which will derive the greatest benefit from electrical working, and into the load factor of barn machinery. At present the typical barnyard engine is a fairly large one of, say, 10-15 h.p., which is regularly called upon to develop full power but which nevertheless will probably not do more than 500 hours of work in a year. As the report points out, running conditions as irregular as these are fundamentally wrong whatever the form of power used, and would be quite unacceptable to the supply engineer who might have to deal with some hundreds of similar cases in his distribution area. The remedy is, of course, the use of lower powered units which run for longer periods, but these will lead to uneconomical labour charges if they are not made practically automatic in operation, while to make them so will involve a considerable measure of barnyard reorganization. The Association's research programme includes some experimental work on these lines, and in the particular case of the grinding mill-the worst offender from the power factor point of view-useful progress has already been made.

In some of the more specialized branches of agriculture, electricity has more to offer than the mere replacement of one form of power by another. In dairying it has overwhelming advantages on grounds of cleanliness alone; while in poultry husbandry it has already been largely responsible for a great increase in chick production. At one time electrical incubation and rearing were regarded as being suit. able only for raising 'soft' chicks for the table. Now, however, it is being realized that the same methods are even more suitable for the rearing of hardy stock. It has been found in practice that the dangers of loss from temporary failure of supply are not so serious as was once thought possible, and with the development in the future of storage brooder heating units these dangers will be reduced still further.

In horticulture, less progress has been made because the industry depends mainly on sources of low-grade heat with which, at any rate in the larger-scale commercial applications, it is difficult for electricity to compete economically. In small-scale work and in the amateur greenhouse, on the other hand, sheer economy of working is not always the ruling consideration. In horticulture generally, however, there is plenty of scope for research and experiment : on the use of heating cables for hotbeds, on soil sterilization, and on the use of light for irradiating growing plants.

The last of these is only one of a number of very interesting future possibilities which are dealt with separately in the concluding section of the report. Among others that may be mentioned are crop drying, grain sprouting, electro-culture and ultra-violet irradiation. At the moment their interest may be academic rather than practical; yet they may very well change the face of agriculture in the not too distant future. 
The report as a whole deals with the situation as it existed at the outbreak of war ; and it cannot be expected that much further progress will be made within the next year or two. At the same time, as is pointed out in an introductory footnote, the War has brought many of the potential advantages of electricity into even sharper relief. From a shortage of cod liver oil comes a new interest in ultra-violet irradiation; the more frequent use of female labour makes ease of control an important consideration; scarcity of imported feeding stuffs encourages a return to the earlier practice of grinding and preparing foodstuffs on the farm; and so on. But, in his final summary, the author of the report takes the longer view and looks forward to the time, twentyfive or forty years hence, when on all but a small proportion of unreachable farms electricity is used as a matter of course, for all stationary power and for all heating operations. This state of affairs is very likely to come about-not, perhaps, as the direct result of technical or agricultural research, but as a matter of sociological progress. The future of agriculture in Great Britain is bound to depend a great deal on giving the rural dweller his due share of urban amenities, and in America it is recognized already that the seller of electric kettles, cookers and washing machines plays a great part in the spread of farm electrification.

\section{FORESTRY IN AFRICA}

$\mathrm{I}^{\mathrm{T}}$ is interesting to note in recent annual forestry reports how what may be termed a correct and long-sighted forest policy is gradually becoming recognized by the civil administration as a matter which can no longer be left to chance. This has recently been exemplified in Nature. In the Gold Coast annual report (1938-39, Govt. Printer, Accra, 1939) the Conservator, in discussing the history of the forests, says that though some thirty-one years ago the indirect value of the maintenance of a proportion of tropical lands under forest was clearly stressed, yet the progress of reserving forests for the use of future generations, the maintenance of soil fertility, and so forth, has not proved an easy task. Forests, of necessity, occupy land, he says; and difficulties are increased when all the land, although surplus to immediate wants, is owned by a community with an unawakened national sense; to the indivividuals the cash resulting from an immediate sale is much to be preferred to the somewhat abstruse prospects from reservation in favour of future generations or a possible improvement in their water supplies. The failure to press for a more rapid selection of forests for reserves when surplus land was plentiful has resulted in an increasing opposition which education and propaganda are only gradually lessening; while the remaining forests of the Colony can no longer be regarded as excessive if the happiness and health of the community are to be assured.

In the Nigerian forestry report for 1939 (Govt. Printer, Lagos, 1940) the Conservator re-defines the aims of forestry in that part of West Africa on the well-known lines which have been so often in the past disregarded by the Governments. He sounds a wise note, too often neglected, that the productive motive, though secondary (it has usually been placed first), is an important one. "If," he says, "forest, shelterbelts and shade trees have to be maintained for protection, it is clear that the fullest possible use should be made of them, and this can best be effected by fostering African industries using forest produce as raw material." These industries, as was foreseen several years ago by senior French district administrative officers in the Ivory Coast, will in the future be more important in the economy of the country than any export trade in timber overseas. It is a step in advance that the head of a West African Forest Department should at length express this important view. The Conservator remarks that the Department is becoming continually more involved, with other rural departments, in the study of the wider problems of land use and land planning. But here again new forest reservation, so urgently needed, proceeds slowly in the south owing to political and legal difficulties and problems of land tenure; and this in spite of the fact that all the forms of deterioration - of soil, climate and water supply -are in active progress in various parts of the southern provinces. There can be little hope of more than local remedy until the chaotic situation as regards land tenure is resolutely tackled.

The annual forestry report for Kenya for 1939 (Govt. Printer, Nairobi, 1940) strikes rather a different note. The outbreak of war has caused some reduction of the staff (junior officers allowed to join or called up to join the Army, which has been the case in both Nigeria and the Gold Coast), but has considerably increased the demand for forest produce. This latter and the increased revenue thereby realized might have proved of some satisfaction to the Department-especially the revival in the old export trade of boritis (mangrove) poles-were it not for the former factor. The demand for produce from the forests was increased during the latter part of the year by War Department demands. At all sawmills trade was fairly brisk, and several millers increased their output considerably by improved organization and efficiency. Unfortunately the urgent military demand for building timber has meant that air-seasoning has not been possible prior to the delivery of the timber.

Regrettable as this may seem, equally unfortunate is the fact that most of the timber requisitioned by the military authorities in war-time is utilized for purposes often ephemeral and in any event has a comparatively short life. A far more important point is the factor that, with a reduced staff, who is to undertake the necessary supervision over the extra fellings which are to take place ? The limit to further indiscriminate fellings and resultant ultimate dis appearance of the African forests has been reached, or is perilously close. If war fellings are to take place unchecked in forests the volume content of which is but imperfectly known, neither administration nor the local forest department is fulfilling its true functions to the native communities. 